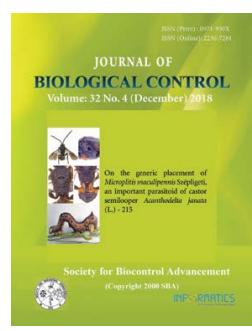

Research Note

\title{
The nematicidal property of aqueous crude extract of Calotropis procera on tomatoes (Lycopersicum esculentus)
}

\author{
C. ANIH AGATHA and V. LAWAL THANK GOD \\ Department of Biological Science, Nigeria Police Academy, Wudil, Kano, Kano state Nigeria; \\ Corresponding author E-mail: esath_agatha@yahoo.com
}

\begin{abstract}
The Efficacy of the aqueous crude extract from Calotropis procera Linn. on the growth and production of tomatoes Lycopersicum esculentus Mill. infested by Meloidogyne javanica was investigated. An aqueous crude extract of Calotropis procera Linn. was prepared by soaking $2 \mathrm{~kg}$ of dried powdered leaf in the ratio of $1: 5 \mathrm{mg} / \mathrm{ml}$ for 24 hours; this was sieved and concentrated with water bath at a controlled temperature of not above $60^{\circ} \mathrm{C}$ also freeze dried to obtain $487 \mathrm{~g}$ of the dried crude extract. The plant pot of tomatoes infested with Meloidogyne javanica was treated with different concentration of the extracts. Treatment with $50 \%$ concentration of the stock solution of $C$. Procera showed significant growth and yield of tomato. Plant height was $83.3 \mathrm{~cm}$ whereas in control it was $68.3 \mathrm{~cm}$. Significant differences in all other parameters were also obtained. Plant height at final harvest was $89.6 \mathrm{~cm}$ as compared to control $(74.3 \mathrm{~cm})$. A positive effect was seen in reducing the number of nematodes both in the soil and in the root. The treatment showed a root gall index of 2.3 which was lowest as compared to control (7.3). Hence at adequate concentration of C. procera extract it is possible to inhibit the nematode attack in tomato.
\end{abstract}

KEY WORDS: Calotropis procera, efficacy, Lycopersicum esculentus, Meloidogyne javanica

(Article chronicle: Received: 09-07-2018; Revised: 10-11-2018; Accepted: 15-12-2018)

Root-knot nematodes of the genus Meloidogyne are among the main pathogens of tomato (Lycopersicon esculentum) crop worlds wide. Infected plants show an aberrant development of the root system characterized by the formation of typical galls, which after the uptake of water and nutrients will interfere with the translocation of minerals and photosynthates (Williamson and Kumar, 2016). As a result above ground deficiency symptom appear which may lead to severe yield decreases, depending on the severity of the infestation. Chemical nematicides are considered as toxic to living animals and human. Because of the adverse effects associated with the use of chemical nematicides; breeding for plant resistance is currently considered as the method of choice for controlling root-knot nematodes. Resistance to Meloidogyne spp. was observed originally in some accession of the wild tomato species L. peruvianum (Bailey, 2014) and subsequently it was shown that the dry powder leaves of Calotropis procera could suppress root knot nematodes. (Gilbert, 2015). Further studies demonstrated that dried powder leaves of $C$. procera could control three major species namely M. arenaria, M. javanica and M. incognita (Barham, 2015). The M1 gene was transformed from $L$. peruvianum
P1128657 into L. esculentum using embryo rescue (Smith, 2014). From the initial inter-specific cross one single $F_{1}$ Plant was used for further breeding by repeated backcrossing, resistant tomato. Cultivars were derived from this single $F_{1}$ plant (Roberts, 2016). Although highly efficient in most cases, pathogenic variability of root knot nematodes raises concern about the durability of the resistance (Serno, 2012) first, although the $C$. procera should block nematode development at an early stage, occurrence of and variation in Meloidogyne spp. reproducti on on $M 1$ gene resistant tomatoes genotype has been documented by Thomason (2013). Secondly nematode biotypes resistant to the $M 1$ gene have recently been described from most of the tomato growing area in the world (Ornat, 2011).

Scarcity, high cost, environmental safety and global restrictions on the importation of chemical nematicides have spurred scientists to search for alternative control measures against nematode pests, that occur in economically important food crops (Anonymous, 2004). The use of plant extracts for the control of nematode pests had been suggested (Hoan and David, 1979). The application of 
plant extracts into the soil has the potential advantage of being economical, ready available and environmentally safe (Olabiyi, 2004). Maqbool et al. (1987) laid emphasis on adopting organic agriculture i.e. agricultural production without the application of synthetic chemicals (fertilizers, pesticides, herbicides and antibiotics). Plant extracts from few plants was shown to suppress nematodes in Nigeria. Root extracts of siam weed (Chromolaena odorata), neem (Azadiratchta indica), castor oil (Ricinus communis), lemon grass (Cypogon citrates) (Adegbite, and Adesiyan, 2005); and root bark extracts of Bixa orellana (Oladoye et al., 2007) showed nematicidal effect. Root and leaves of Africa marigold (Tagetes erecta), rattle weed (Crotalaria retusa), nitta (Hyptis suaveolens) and basil, Ocimum gratissimum (Olabiyi, 2004) were also effective. The leaf, stem, root, flower extracts of Africa marigold, Tagetes erecta (Oyedunmade, 1998), neem (Azadirachta indica) fruit extracts were also reported to be effective.

Fresh leaves of Calotropis procera were collected from an open field of Nigeria Police Academy Wudil, Kano during November 2016 to February 2017. These were brought to the laboratory for identification using a standard key according to Daziel (1937) and a sample of it was deposited in the hebarium for future reference. Samples of the plant were dried inside the laboratory at ambient temperature that varied from $25^{\circ} \mathrm{C}$ to $28^{\circ} \mathrm{C}$ for 7 days.

The air dried leaves were pulverized into powder by use of wooden mortar and pestle according to the method of Kela et al. $(1989,1995) .2 \mathrm{~kg}$ of the processed plant leaves was weighed and soaked in distilled water in the ratio of $1: 5 \mathrm{mg} / \mathrm{ml}$. This was stirred and kept for twenty-four hours. Filtration was done using muslin cloth and later filter paper. The filtrate was concentrated by heating in a water bath at varying temperature of $40^{\circ} \mathrm{C}$ to $60^{\circ} \mathrm{C}$ for drying and to obtain $723 \mathrm{~g}$ of crude extract. This was kept in a fridge and stored at $4^{\circ} \mathrm{c}$ until needed.

Sandy-loam soil was used for planting; this was sterilized by heating twice at an interval of 12 hours at $100^{\circ} \mathrm{C}$ for 4 hours according to the method of Gautam and Goswami (2002). The soil was left to cool for twentyfour hours and stirred for aeration before putting into perforated experimental pots at the rate of ten kilogram per pot. The pots were placed on a metal stand to avoid nematodes or microbial reinfestation from the adjourning soil and were kept in a control room for three days stabilize before planting.

Tomato seeds were obtained from an open market in Wudil, Kano. It was taken to the laboratory for viability test and planting of the seeds was carried out in the months of
April and July 2017. The sand-filled pots were arranged in triplicates by five columns. This was labelled accordingly as $\mathrm{T}_{1}-\mathrm{T}_{5}$ for different concentrations of the extracts of treatment.

Galled roots of infected tomatoes were collected from a local farm in Wudil Kano. They were washed gently in water with a hair brush to remove the sand and plant debris was brought to the laboratory. The roots were then chopped into fine pieces and $5 \mathrm{~g}$ of infected root galls were applied in the soil around the crop at 4 WAP (weeks after planting). The extraction of the nematode was done using the modified bearmann funnel method. Samples were kept for about 24 hours to allow the active nematode from the moist into collecting tube containing water. The suspension was collected in a beaker to allow the nematodes to settle for few hours. The juveniles collected were viewed under a binocular microscope and was identified with a standard key for identification according to Mekete (2012).

Ten days after nematode inoculation, the plants were treated with the crude leaf extracts of $C$. procera at various levels including that of $0 \%$ concentration (distilled water only). The concentrated crude extract was serially diluted with distilled water to get different stock solutions. The ratio of concentrate : distilled water were prepared as $3: 1$ (75\%), 1:1 (50\%) and 1:3 (25\%) according to the method of Oyedumade (1998). Stock solutions were applied @100ml per pot ring-round.

Data collected during the experiment includes: plant height before nematode inoculation (initial population) was counted to be $20 \pm 5$, plant height on weekly measurement for 12 weeks (PHOW12). This was taken from the second week after transplanting, number of days to flowering (NODTF), number of fruits per pant at final harvest, number of leaves at flowering (NOLAF), Fresh Weight of Fruit Per Plant at Harvest (FWOPPAH), number of nematode per $100 \mathrm{ml}$ of soil at harvest, root gall index per plant (RGIPP), number of nematodes per $5 \mathrm{~g}$ of root at harvest (NONP5GR). The experimental data were subjected to Analysis of variance and treatment means were compared using Duncan's New Multiple Range Test (DNMRT) at 5\% level of significance using Statistical Package for Social Science (SPSS) version 20.0 .

From the results obtained, treatment with 50\% concentration of the stock solution of $C$. procera showed significant growth and yield of tomato. Plant height was $83.3 \mathrm{~cm}$ whereas in control it was $68.3 \mathrm{~cm}$. Significant differences in all other parameters were also obtained (Table 1). Fresh weight of fruit per plant was $92 \mathrm{~g}$ and in control $74 \mathrm{~g}$ and plant height at final harvest was $89.6 \mathrm{~cm}$ as compared to control $(74.3 \mathrm{~cm})$. 
Hence tomato plants responded positively to treatment $50 \%$ stock solution of $C$. procera extract.

Observations on the root gall indices showed that there was a nematode attack on the crop and plants treated with $50 \%$ concentration of extract showed a positive effect in reducing the number of nematodes both in the soil and in the root Table 2). From a initial nematode population of 20

\section{Table 1. Effect of different concentrations of extracts of Calotropis procera on the growth of root knot nematode infested Tomat}

\begin{tabular}{|c|c|c|c|c|c|c|c|}
\hline 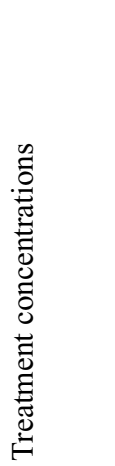 & 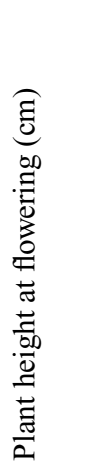 & 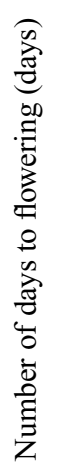 & 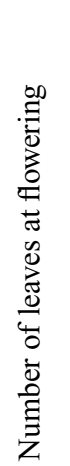 & 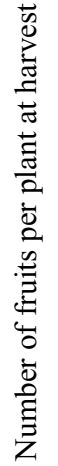 & 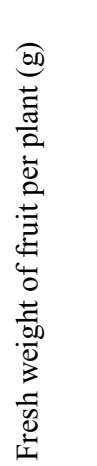 & 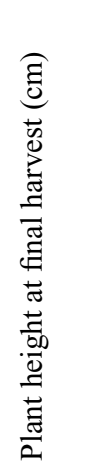 & 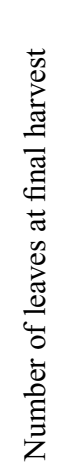 \\
\hline $100 \%$ & $75.6^{\mathrm{ab}}$ & $36^{\mathrm{ab}}$ & $12^{\mathrm{b}}$ & $3^{\mathrm{a}}$ & $93.3^{\mathrm{a}}$ & $82.3^{\mathrm{b}}$ & $17^{\circ}$ \\
\hline $75 \%$ & $72.3^{\mathrm{ab}}$ & $41^{\mathrm{b}}$ & $15^{\mathrm{b}}$ & $2^{\mathrm{a}}$ & $77.6^{b}$ & $70^{\mathrm{d}}$ & $23^{b}$ \\
\hline $50 \%$ & $83.3^{\mathrm{a}}$ & $27^{\mathrm{a}}$ & $21^{\mathrm{a}}$ & $2^{\mathrm{a}}$ & $92^{\mathrm{a}}$ & $89.6^{\mathrm{a}}$ & $28^{\mathrm{a}}$ \\
\hline $25 \%$ & $70.3^{\mathrm{ab}}$ & $39^{\mathrm{b}}$ & $19^{\mathrm{a}}$ & $1^{\mathrm{ab}}$ & $73.3^{\mathrm{bc}}$ & $74.3^{c}$ & $24^{b}$ \\
\hline Control & $68.3^{\mathrm{b}}$ & $41^{b}$ & $11^{\mathrm{b}}$ & $2^{\mathrm{a}}$ & $74^{\mathrm{bc}}$ & $74.3^{\mathrm{c}}$ & \\
\hline
\end{tabular}

Means followed by the same values are not significantly different $(p=0.05)$ according to Duncan's Multiple Range Test

Table 2. Effect of different concentrations of extracts of Calotropis procera on Meloidogyne javanica multiplication

\begin{tabular}{|c|c|c|c|}
\hline 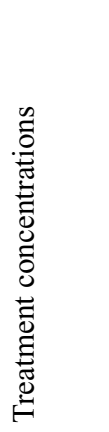 & 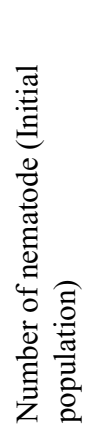 & 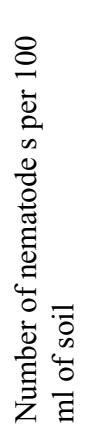 & 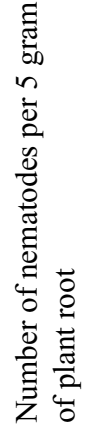 \\
\hline $100 \%$ & 20 & 7.3ab & $5 a$ \\
\hline $75 \%$ & 20 & $16.3 \mathrm{c}$ & $10 \mathrm{~b}$ \\
\hline $50 \%$ & 20 & $6 a$ & $4.3 \mathrm{a}$ \\
\hline $25 \%$ & 20 & $6.6 \mathrm{a}$ & $11.6 b$ \\
\hline Control & 20 & $16.6 \mathrm{c}$ & $17.3 \mathrm{c}$ \\
\hline
\end{tabular}

Means followed by the same values are not significantly different $(p=0.05)$ according to Duncan's Multiple Range Test it was reduced to 4.3 per $5 \mathrm{~g}$ of root whereas in control it was 17.3. The treatment showed a root gall index of 2.3 which was lowest as compared to control (7.3).

Hence, at adequate concentration of $C$. procera extract it is possible to inhibit the nematode attack and existence both in the soil and in the root and when used @ 50\% it had better effect in reducing the population of nematode.

\section{REFERENCES}

Bailey SR. 2014. Calotropis procera fiber, apartment reinforcement agent for thermoplastic composites. J Reinf Plast Comp. 17: 2143-2149.

Gilbert OC. 2015. Calotropis procera: A new and free source of fibre and renewable hydrocarbons. J Agric Mech. 3: 71-75.

Ornat LM. 2011. A study on the antisperm activity extracts from different parts of Calotropis procera. Pak J Zool. 2: 161-166.

Serno BN. 2012. Parasitic strategies of root nematodes' and associated host cell responses. J Phytopathol. 31: 235259.

Smith DL. 2014. Influence of temperature on Meloidogyne javanica J Med Plants. 40: 230-243.

Dalzel JM. 1948. The useful plants of West Africa (being an appendix to the flora of West Tropical Africa. In: Hutchinson J, Hunshel JM and Dalziel DR. (Eds.). Crown agents for the colonies. London.

Adegbite AA, Adesiyan SO. (2005). Root extracts of plants to controlroot-knot nematode on edible soybean. World JAgric Sci. 1(1): 18-21.

Oladoye SO, Olabiyi TI, Ayodele ET, Ibikunle GT. 2007. Photochemical screening and nematicidal potential of root bark extract of Bixa orellane on nematode pests. Res Crops. 8(1): 222-228

Maqbool MA, Hashmi S, Ghaffar A. 1987. Effect of latex extracts from Euphorbia caducifola and Calotropis procera on root knot nematode growth and yield of tomato. Pak J Nematol. 5: 43-48.

Mekete T, Dababat A, Sekora N, Akyazi F, Abebe E. (comps). 2012. Identification key for agriculturally important plant-parasitic nematodes Prepared for the International Nematode Diagnosis and Identification Course 2012 - A manual for nematology. Mexico, D.F.: CIMMYT. 
Kela, SL, Ogunsusi, RA, Ogbogu VC, Nwude N. 1989a. Susceptibility of 2-week old Lymnea natalensis to some plant extracts. Rev Elev Med Pays Trop. 42(2): 189-195

Kela SL, Bowen ID. 1995b. Histopathological effects of Deterium microcarpum, a naturally occurring plant molluscide on the mid gut and digestive gland of Lymnea stagnalis. Cell Biol Int. 19(3): 175-181 https://doi.org/10.1006/cbir.1995.1060

Guatam C, Goswami BK. 2002. Different combinations of neem cake and carbofuran against Meloidogyne
Meloidogyne incognita on Vigna radiata. Int J Nematol. 12(1): 106-110.

Oyedumade, EEA. 1998. Oyedumade, EEA. 1998. Control of nematode pests of cowpea with mecarp (Ethoprop), leaf residues of neem (Azardirachta indica). Rattle weed (Crotalaria retusa) and Hyptis suaveoleus). Centre Point 8(1): 57-63.

Williamson V, Kumar A. 2016. Nematode resistance in plants: The battle underground. Trends Genet. 22(7): 396-403. https://doi.org/10.1016/j.tig.2006.05.003PMid:16723170 